\title{
For the Wind Is in the Palm-Trees: The 2017 Rohingya Crisis and an Emergent UK Approach to Atrocity Prevention
}

\author{
Kate Ferguson \\ Co-Executive Director, Protection Approaches, London, UK \\ Chair of Policy, European Centre for the Responsibility to Protect, Leeds, UK \\ Kate.Ferguson@protectionapproaches.org
}

\begin{abstract}
This article explores the British government's recent Myanmar policy, its response to the Rohingya crisis of 2017, and the extent to which increasing scrutiny from parliament and civil society in reaction to the atrocities in Rakhine prompted clearer articulation of a national approach to atrocity prevention. The article presents five key failures and argues that a goal for those wishing to preserve and strengthen the principle of the Responsibility to Protect, and advance the goal of preventing mass atrocities, must be to break it free of the United Nations sphere and integrate the pillars into state structures.
\end{abstract}

\section{Keywords}

atrocity prevention - foreign policy - global Britain - human rights - Rohingya - $\mathrm{R}_{2} \mathrm{P}$

For the wind is in the palm-trees, and the temple-bells they say: "Come you back, you British soldier; come you back to Mandalay!"

'MANDALAY', RUDYARD KIPLING, 1890 Recited by then Foreign Secretary Boris Johnson in Shwedagon Pagoda, Yangon, in January 2017 
The rapid forced displacement of Rohingya communities in Rakhine State during August and September 2017 provoked outcry from the United Kingdom's parliament, civil society and - in time - from government. ${ }^{1}$ The atrocities committed against Rohingya communities in Myanmar was one of the few issues to penetrate the Brexit bubble. The speed with which the Tatmadaw campaign was carried out and the scale of the civilian suffering dominated public expressions of concern, prompting a familiar humanitarian discourse and policy response that focused upon the immediate needs of the refugees in Bangladesh but remained reluctant to engage with the political logic of the violence. In this sense, Westminster's reaction to the Rohingya atrocities was not much different to Syria since 2011, Sri Lanka in the mid-20oos, or Bosnia in the early 199os. However, anger at the apparent failure of Her Majesty's Government (HMG) to foresee or prepare for this violent crisis drew increasing scrutiny that focused on the absence of a national strategy, clear policy, or identifiable approach tasked with guiding UK responses to the urgent threat of impending or ongoing atrocity crimes. In New York, despite being 'penholder' on the issue at the United Nations Security Council, leadership at the multilateral level was lacking before, during, and in the wake of the crisis. ${ }^{2}$

In response, civil society and parliamentary efforts came together, raising, in some cases for the first time, concerns over gaps in UK policy rather than solely focusing on the humanitarian consequences of the Rohingya atrocities. In December 2017, the Foreign Affairs Parliamentary Select Committee Inquiry into the violence in Rakhine and the UK's response concluded that the ongoing crisis in Myanmar was 'sadly predictable and predicted' yet the Foreign Office warning system did not 'raise enough alarm. There was too much focus by the UK and others in recent years on supporting the 'democratic transition' and not enough on atrocity prevention. ${ }^{3}$ Interviews in 2019 with current and

1 I'm very grateful to those from the UK government who spoke to me on the condition of anonymity or off the record, and for the official responses I received to written questions. My conclusions are therefore informed by the personal views of those who were or remain close to the UK's Myanmar policy as well as official policy. Special thanks to Savita Pawnday, Alexandra Buskie, Fred Carver, Martin Mennecke, Jason Ralph, and Ellen Stensrud, whose ideas and edits helped shape this paper. Thanks to Nasyah Bandoh and Detmer Kremer for editorial support. Any errors are unintentional but my own.

2 On multilateral failures see Noel M. Morada, 'Continuing Violence and Atrocities in Rakhine since 2017: Beyond the Outrage, Failures of the International Community', Global Responsibility to Protect, 12(1) 64-85 (2020); Simon Adams, 'The Responsibility to Protect and the Fate of the Rohingya', Global Responsibility to Protect, 11(4) 435-450 (2019).

3 House of Commons Foreign Affairs Select Committee (FASC), Violence in Rakhine State and the UK's Response, First Report of Session 2017-19, HC435, 6 December 2017, p. 3; Protection 
former officials from the UK's Myanmar country team found that no discernible framework of atrocity prevention was or had ever been applied to UK decision making and that institutional understanding of identity-based mass violence and atrocities as being distinct from HMG's conceptualisation of conflict was low. Interviews with HMG staff in Myanmar and London revealed poor and irregular communication that inhibited in summer 2017 timely information sharing and analysis of UK options.

While HMG did not respond quickly to the concerns mounting in late 2017 and throughout 2018 regarding the absence of a UK atrocity prevention strategy, in summer 2019 the Foreign Office (FCO) published for the first time a 'national approach to preventing mass atrocities' which set out in a policy guidance note that UK contributions to atrocity prevention now fell across not only the FCO but also the Department for International Development and the Ministry of Justice. ${ }^{4}$ This note fell short of the comprehensive national strategy NGO s and the parliamentary committees were calling for but it marked a significant normative shift in how the UK government talked about atrocity prevention and its Responsibility to Protect $\left(\mathrm{R}_{2} \mathrm{P}\right)$, moving away from a habit of 'passing up' to the United Nations and British contributions to protective armed action or 'humanitarian intervention'. This conceptual shift towards the conscious integration of atrocity prevention was seen too in the 2020 publication of the UK's refreshed approach to protecting civilians in conflict, which not only included a fleshed out section on the Responsibility to Protect but also identified atrocity prevention as an integral component of the UK's conflict prevention work. ${ }^{5}$ On a country level, by spring 2020 the UK's Myanmar Unit was developing what it called a framework of atrocity prevention, building out a set of risk indicators specific to identity-based violence and atrocities, reviewing its country-wide strategy from an atrocity prevention perspective, exploring options to establish a fund for local atrocity prevention activities, and developing training options for UK staff in partnership with civil society

Approaches, Written Evidence Submission to the Foreign Affairs Committee, Bu Roo23, October 2017. See also Eglantine Staunton and Jason Ralph, 'The Responsibility to Protect Norm Cluster and the Challenge of Atrocity Prevention: An Analysis of the European Union's Strategy in Myanmar', European Journal of International Relations, 26(3) 66o-686 (2019), which identified similar findings in EU policy.

4 Foreign \& Commonwealth Office and Foreign, Commonwealth \& Development Office (FCO and FCDO), UK Approach to Preventing Mass Atrocities, Policy Paper, 16 July 2019.

5 Department for International Development, Foreign \& Commonwealth Office, and Ministry of Defence, UK Approach to Protection of Civilians in Armed Conflict, Policy Paper, 27 August 2020 , box 5 . 
partners. This is formative work for the UK and could well set a precedent for UK country teams elsewhere as well as other embassies in Yangon.

The impact of these modest but significant changes in how HMG approaches atrocities and the embassy's efforts to embed atrocity prevention across the UK's Myanmar strategy will depend on how these new commitments are integrated into the new Foreign, Commonwealth and Development Office and the extent to which in-country efforts are backed by London and the UK's international partners. It is likely that, while difficult to prove, implementation of a new atrocity prevention communications protocol was able in June 2020 to respond to Tatmadaw attacks of villages and reports of sexual violence in Rakhine in a manner that greatly improved the speed and quality of information being passed from the field to the embassy and then on to Whitehall and New York. Cautious internal assessment concluded that these actions helped the UK to mobilise partners at the UN and probably elicited the subsequent de-escalation from the Tatmadaw. ${ }^{6}$

This article discusses the political and bureaucratic obstacles that inhibited a more effective response from the British government to the rising and well-reported threats facing Rohingya communities before and during summer 2017. Drawing on interviews with current and former HMG staff who spoke to me on the condition of anonymity or wholly off the record, an official response to my written questions from the UK government, the UK parliamentary record, and publicly available policy documents, I present five failings but show too how reactions to the atrocities in Rakhine encouraged changes in the UK's Myanmar strategy as well as more normative shifts towards atrocity prevention in Westminster discourse. The article concludes with recommendations for national governments resolved to replicate in national policy the commitments they have made on the multilateral level to the prevention of and protection from mass atrocities.

\section{Devolving and Domesticating R2P}

When a state fails to protect populations within its own borders from mass atrocity crimes, the responsibility to safeguard groups at risk falls to the international community. The responsibility is at its heart a collective one and its successful implementation requires considerable coordination among a

6 Reuters staff, ‘Thousands in Western Myanmar Flee as Army Plans Operations, Monitors Say', Reuters, 27 June 2020, https://uk.reuters.com/article/uk-myanmar-rakhine/thousands-inwestern-myanmar-flee-as-army-plans-operations-monitors-say-idUKKBN23 YoPZ, accessed on 16 December 2020. 
diverse group of actors. Yet $\mathrm{R}_{2} \mathrm{P}$ and atrocity prevention architectures, where they exist at all, remain fragmented. As with effective strategies for tackling other global challenges such as the climate crisis or the CoviD-19 pandemic, the prevention of atrocities requires state-level actions that uphold commitments made in multilateral fora, whether at the United Nations or via regional organisations. ${ }^{7}$ Likewise, successful state-level contributions to the goal of protecting populations from atrocities, whether in their domestic or international policy, require input from and coordination with civil society actors, whether NGOS, affected communities, religious leaders, or other experts.

The collective nature of $\mathrm{R}_{2} \mathrm{P}$ does not dilute the function of the state as a means of contributing to the actualisation of the three pillars but rather underscores it. UN Secretary-General Guterres has called for member states to develop national mechanisms on atrocity prevention and integrate norms and tools in existing policy processes while the UN-World Bank study Pathways for Peace concluded both national and international attention must urgently be refocused on prevention. ${ }^{8}$ Successful domestication of $\mathrm{R}_{2} \mathrm{P}$ requires the integration of prevention and protection into domestic policies to safeguard all populations within domestic borders, and into national development, foreign and defence policies in order to be able to properly contribute to the safeguarding of populations abroad. That the principle of $\mathrm{R}_{2} \mathrm{P}$ continues to be disproportionately viewed by its champions and critics as a tool of multilateral policy - and particularly of the UN Security Council - has been perpetuated by real and perceived overemphasis in $\mathrm{R}_{2} \mathrm{P}$ discourse and fields of practice of the third pillar, specifically protective or preventative armed action, which must necessarily remain the purview of the Security Council as per international law. ${ }^{9}$ With the Council finding itself increasingly in deadlock on

7 Dominique Strauss-Kahn, 'Global Challenges, Global Solutions', Address, George Washington University, Washington, DC, 4 April 2011. For examples, see United Nations Sustainable Development Goals (UN General Assembly, Transforming Our World: The 2030 Agenda for Sustainable Development, A/RES/70/1, 21 October 2015) and United Nations Framework Convention on Climate Change Paris Agreement (United Nations, Paris Agreement [Paris: United Nations, 2016], pp. 1-27).

8 António Guterres, Implementing the Responsibility to Protect: Accountability for Prevention, A/71/1016-S/2017/556, 10 August 2017; United Nations and World Bank, Pathways for Peace: Inclusive Approaches to Preventing Violent Conflict (Washington: World Bank Group, 2018).

$9 \quad \mathrm{R}_{2} \mathrm{P}$ literature focuses overwhelmingly on its success and or limits at the UN and particularly the Security Council. Likewise, NGO efforts have traditionally focused on facilitating or monitoring state promotion of the principle within the UN system. Interviews with HMG officials and analysis of the parliamentary record find that in the UK R2P is, where it is understood at all, almost always viewed as a tool of the Council. 
issues of prevention and protection, and the norm of $\mathrm{R}_{2} \mathrm{P}$ - indeed broader agendas of atrocity prevention and human rights - facing growing strain, the need for states to match their rhetorical support and multilateral activity with substantive national-level reform seems clear. Until the principle of collective responsibility to help protect those vulnerable to atrocity crimes is seen as something that stretches from individuals to global leaderships, encompassing states, parliaments, civil society, the private sector, media, and other elements of our local, national, and global societies, the potential impact of $\mathrm{R} 2 \mathrm{P}$ will remain constrained. The goal for those wishing to preserve, promote, and strengthen the principle is therefore to 'open up' how $\mathrm{R}_{2} \mathrm{P}$ is understood, 'taking it out' of the UN, and integrating it into state structures and civil society practice. Pluralising conceptual access to, and invocation of, the three pillars would neither remove or reduce R2P's influence at the UN but represent better mainstreaming the norm and build consolidated means of joined-up operationalisation.

Since 2005, successive UK governments have reiterated their commitment to the UN principle of $\mathrm{R}_{2} \mathrm{P}$. It is a strong supporter of the agenda at the United Nations and participates in discussions to share good practices for how to translate this commitment into policy and practice. ${ }^{10}$ Preventing conflict and building stability overseas is enshrined in numerous UK policy strands as being fundamental to the national interest. ${ }^{11}$ However, unlike in the US, states in Latin America and Africa, or the European Union, in 2017 the UK had yet to adopt a clear approach to atrocity prediction, prevention, or response. ${ }^{12}$ Historically, a major obstacle to progress in the UK has been persistent

10 The UK is a member of the Group of Friends of $\mathrm{R}_{2} \mathrm{P}$ and was an early adopter of a nationallevel focal point for $\mathrm{R}_{2} \mathrm{P}$ even if it remains a role requiring greater clarity, convening capacity, and resources. The UK funds the Global Centre for the Responsibility to Protect and the UN Joint Office for the Prevention of Genocide and the Responsibility to Protect.

11 Department for International Development, Foreign \& Commonwealth Office, and Ministry of Defence (DFID, FCO and MOD), Building Stability Overseas Strategy, 1 July 2011; The Cabinet Office, Her Majesty's Government, National Security Strategy and Strategic Defence and Security Review 2015: A Secure and Prosperous United Kingdom, Cm 9161, 23 November 2015 .

12 While the US and EU 'look out' towards international threats, mechanisms in Latin American and African States tend to, but do not always, 'look in' towards domestic risks. See Samantha Capicotto and Rob Scharf, 'National Mechanisms for the Prevention of Atrocity Crimes', Genocide Studies and Prevention: An International Journal, 11(3) 6-19 (2018). 
reluctance to acknowledge the challenges posed by mass atrocities and identity-based violence as being distinct from the agenda of preventing conflict. ${ }^{13}$ Another was, before 2015 and again unlike many other parts of the world, the absence of a UK-based civil society tasked explicitly with looking at national contributions to atrocity prevention. As a result, UK efforts to address mass atrocities have tended to 'too often fall between the cracks of conflict prevention, tackling violent extremism, and international development; or between the Department for International Development (DFID) and FCo'.14

These challenges are not unique to the UK. Many states that show support for $\mathrm{R}_{2} \mathrm{P}$ in New York have yet to domesticate those commitments. Misconceptions of what atrocity prevention and identity-based violence prevention entail continue to stymie effective policy, advocacy, programming, and funding. However, the pervasiveness of these common obstacles to effective implementation of $\mathrm{R}_{2} \mathrm{P}$ only emphasises the need to focus, on a specific and national level, how such gaps and errors can be corrected. The five failures of UK policy detailed below are very likely shared by others.

Scholarly assessment of the progress, impact, and limitations of $\mathrm{R}_{2} \mathrm{P}$ has often been made from the perspective of how norms evolve and proliferate (or do not). ${ }^{15}$ On a working level at least, the UK's limitations when it comes to $\mathrm{R}_{2} \mathrm{P}$ and atrocity prevention have to do with practical obstacles of competing priorities and genuine lack of clarity of what precisely the UK should be doing to better uphold its albeit limited understanding of its responsibility in the most explicit cases where mass atrocities are already evident. This is not withstanding the wider British row-back in recent years by Prime Ministers Theresa May and Boris Johnson from related principles such as multilateralism and even international law. This contestation between officials trying to help prevent the loss of life overseas and a growing populist politics promoted by Number 10 is an important background to the discussion below.

Following a robust exchange during a public evidence session in 2018 on UK policy in Syria and Myanmar with the Foreign Affairs Select Committee,

13 This has been the case since at least the UK's policy in Bosnia in the early 199os. See also Jason Ralph, 'Mainstreaming the Responsibility to Protect in UK Policy; a report written for the United Nations Association-UK', UNA-UK, 11 April 2014.

14 Protection Approaches, Written Evidence Submission to the International Development Select Committee Inquiry 'DFID's Work on Bangladesh, Burma, and the Rohingya Crisis' (Dв Bоo14), December 2017 .

15 This is a rich literature to which this journal has greatly contributed to. See Jennifer Welsh, 'Norm Contestation and the Responsibility to Protect', Global Responsibility to Protect, 5(4) 365-396 (2013); Ramesh Thakur, and Thomas G. Weiss, 'R2P: From Idea to Norm-and Action?', Global Responsibility to Protect, 1(1) 22-53 (2009); Amitav Acharya, 'The R2P and Norm Diffusion: Towards a Framework of Norm Circulation', Global Responsibility to Protect, 5(4) 466-479 (2013). 
when asked why the UK lacked an atrocity prevention strategy, the responsible Minister with the Foreign Office ${ }^{16}$ answered 'the fact we believe we can act on the basis of humanitarian intervention allows us to be flexible, and indeed focus in on exactly the point you raise. ${ }^{17}$ In other words, in July 2018 , the UK government saw its approach to the prevention of mass atrocities only in terms of its prevailing understanding of humanitarian intervention. When pushed further, senior civil servant and deputy of the UK's Multilateral Directorate Corrinne Kitsell responded

[w]e co-ordinate across Whitehall on issues such as conflict prevention and we work with the Department for International Development on development. All these things are a part of that picture, and we frame it more through a conflict prevention and development lens than we do through atrocity prevention. ${ }^{18}$

The absence of atrocity prevention thinking was particularly explicit in the Ministry of Defence; the 2016 Foreign Affairs Committee inquiry into the intervention in Libya concluded that 'the UK Government focused exclusively on military intervention' and assessed that the Committee had 'seen no evidence that the UK Government carried out a proper analysis of the nature of the rebellion in Libya.' ${ }^{19}$ No assessment of the atrocity risks was carried out by the UK government prior to its participation in NATO action, nor was there any obvious existing internal mechanism that would have been responsible for such scenario planning, precisely because of the UK's disconnected approach to conflict prevention and development. Such was the state of HMG engagement with the atrocity prevention agenda before and in the immediate wake of the 2017 Rakhine exodus: implementing British commitments to prevent genocide, ethnic cleansing, crimes against humanity, or widespread and systematic violent discrimination fell through the gaps between the UK's international departments as well as its cross-cutting strategic objectives.

It was not that human rights and related agendas were absent from UK overseas strategy; since 2011, UK officials have been required to have an Overseas

16 Lord Ahmad, in 2018 was responsible for multiple related portfolios including Human Rights and the United Nations and subsequently Atrocity Prevention.

17 FASC, Oral Evidence: Responsibility to Protect and Humanitarian Intervention, HC1005, 11 July 2018, Q101.

18 ibid., Q102.

19 FASC, Libya: Examination of Intervention and Collapse and the UK's Future Policy Options, Third Report of Session 2016-17, HC119, 14 September 2016, p. 15. 
Security and Justice Assessment to ensure that British security and justice work defends and promotes human rights. ${ }^{20}$ But while the UK's work on conflict prevention and stabilisation has become vast and well resourced, it has never been clear which overarching policies are driving its interventions and therefore it remains persistently challenging for analysts and advocates to determine how atrocity prevention or identity-based violence more broadly are being treated. Prior to 2017 , the UK had not integrated a specific atrocity prevention framework as part of its overarching national policy approach or within Myanmar. None of the major strategies or policies guiding the UK's approach to prevention explicitly consider atrocity crimes or identity-based violence. ${ }^{21}$ The characteristics and warning signs of identity-based violence have never appeared to be explicitly considered in analysis, early warning, capacity building, programming, and monitoring, raising the potential to overlook the processes that precede atrocities both within and outside situations of armed conflict.

Thus, despite the UK's strong rhetorical support for the atrocity prevention agenda and the responsibility to protect, when the Rohingya atrocities in 2017 occurred, the UK had yet to reflect upon or address the gaps between these commitments made on the multilateral level and their practical implementation on the national.

\section{3}

UK Response to 2017 Atrocities: Five Failures

The 2017 atrocities against Rakhine's Rohingya were the result of a deliberate and systematic effort by the Myanmar military to drive the Rohingya out of Myanmar. They were 'predictable and indeed predicted'. ${ }^{22}$ However, the UK's internationally facing departments, including trade, international development, and the Foreign Office, neither sufficiently recognised nor responded to the warning signs. In this paper I identify five failures of the UK's policy towards Myanmar: the belief that the democratisation agenda was sufficient; the government's process of joint analysis of conflict and stability (JACS) was never undertaken for Myanmar or even Rakhine; UK policy-making in Myanmar included neither a framework of atrocity prevention nor means of

\footnotetext{
20 ibid.

21 For a discussion of the treatment of atrocity prevention in the Building Stability Overseas Strategy and civilian protection, see Ralph, 'Mainstreaming the Responsibility to Protect in UK Strategy'.

22 FASC, Violence in Rakhine State and the UK's Response, HC435, p. 3.
} 
measuring specific indicators of atrocity risks; there was no national strategy or public policy to provide guidance or knowledge on UK contributions to preventing atrocities; and there was neither an internal communications protocol connecting the embassy with relevant parts of Whitehall or New York - nor a central mechanism tasked with coordinating UK policy from the perspective of mitigating or preventing atrocities. The UK's failure to do better was part of a collective failing which could have been mitigated had individual states had the systems, capabilities, and determination to view their Myanmar policies from the perspective of how their actions could best reduce the likelihood of violence against at risk populations.

Domestic factors also contributed to the UK's poor policy in Rakhine. The 2016 referendum on the UK's membership of the European Union had thrown parliament, government, and the press into a Brexit-first work cycle which made it difficult for other issues to penetrate. In 2017 as Foreign Secretary, Johnson made considerable cuts to the Foreign Office causing internal flux and dissatisfaction within the department. The Rakhine crisis occurred during a prolonged period of exceptionally closed UK government relations and British-based civil society found itself shut out. Without the necessary systems and processes in place, responding to the rising warning signs of calamity fell to a Whitehall preoccupied by the most extraordinary political moment in the UK's recent history and, as a result, for whom the prospect of an unfolding genocide in western Myanmar must have seemed politically as well as physically distant.

\subsection{An Overemphasis on Democratisation}

From 2011, as the country began to slowly open up, the UK's Myanmar policy prioritised a traditional three-pronged development strategy aimed at reducing poverty, building an 'inclusive' economy, and assisting the transition to democracy. ${ }^{23}$ As one DFID official put it, 'democratisation was the priority and supporting Aung San Suu Kyi in that endeavour, which was seen unequivocally as the right thing to do at the time. ${ }^{24}$ The UK government saw itself as 'a long standing supporter of democratic transition in Myanmar' and 'the 2015 national elections were a milestone'. ${ }^{25}$ 'The situation of the Rohingya in Rakhine has been a perennial concern in UK-Myanmar relations, ${ }^{26}$ and in the period before the 2017 violence Rakhine was included in the agenda of all

23 Her Majesty's Government Officials, interviewed by the author, London, 17 and 31 July 2019.

24 Her Majesty's Government Officials, interviewed by the author, London, 17 July 2019.

25 Formal response to the author from Her Majesty's Government, received 23 September 2019.

26 ibid. This was a view shared by all officials who I talked to. 
ministerial visits to the countries. The problem was not that Rakhine was never sufficiently prioritised but that policy was guided by the assumption that a localised conflict prevention strategy situated within a wider country strategy rooted in supporting the democratic transition was the best approach.

At the same time, the UK considered itself 'consistent in speaking out about human rights violations' and in a sense that was true. ${ }^{27}$ Since 2012 , the UK has invested $£_{30}$ million in Rakhine State to provide basic services, improve nutrition and livelihoods, and to strengthen mechanisms for community dialogue and representation. ${ }^{28}$ Despite criticisms regarding inconsistencies between the UK's stated human rights objectives in the country and its bilateral trade strategy, Myanmar did not occupy a point of strategic interest and therefore the UK's work on human rights and the drugs trade could continue relatively autonomously. ${ }^{29}$ The UK government was confident that "[a]n understanding of the context and the underlying causal factors of violence in Rakhine State was a fundamental precursor to [HMG] programming. ${ }^{30}$ Unfortunately, the failure to correctly identify causal factors and risks associated with mass atrocity crimes also impacted HMG programming. Moreover, a weakness of the FCO-DFID dynamic often meant that human rights were something to be promoted via specific programmes or diplomatic interventions rather than embedded across HMG thinking and doing. This almost certainly contributed to an avoidable conceptual division between objectives of 'democracy' and 'rights and justice'.

Interviews and analysis of public-facing policy documents suggest the belief in democratisation came from a two-dimensional assessment of Suu Kyi and a sense that it was what other likeminded states, namely the US, were prioritising. It was justified rather than determined by the assumption that a more democratic Myanmar would automatically deliver improved conditions for minorities. The fact that democracy essentially means contestation - and contestation so often falls along fault-lines that already exist or are intentionally awakened for the ballot box, particularly in emerging democratic systems where institutions are less established - does not appear to have been a major concern.

27 Formal response to author from Her Majesty's Government, received 23 September 2019.

28 ibid.

29 This was a point that was made by all officials I spoke to whereas all human rights experts believed HMG had made a strategic decision to privilege bilateral trade above human rights considerations. It is likely that these diverging views between civil society and the UK government, and the failure to either reconcile or address them, hampered advocacy efforts toward the UK government and damaged civil society-HMG relations.

Formal response to the author from Her Majesty's Government, received 23 September 2019. 
Whether it was her charisma, her iconic status as a veteran of democratic struggle, or that her education at Oxford meant she understood the rules of UK diplomatic engagement, the personality and draw of Aung San Suu Kyi was evident. The UK officials who spoke to me on the condition of anonymity believed that what they saw as an overemphasis on the democracy-first approach was a mistake, particularly the decision to prioritise the relationship with Suu Kyi - even if there is little clarity over where responsibility for privileging the relationship actually lay. One official said there was also a reluctance among some senior civil servants to believe the threat to Rohingya communities 'was real'. ${ }^{11}$ Minister for East Asia Mark Field was candid in December 2017; " [w] do need to look back at precisely the way in which, in the midst of that move towards any sort of democracy, a blind eye was turned to the ongoing plight of the Rohingya, of which we were aware some time before.' ${ }^{32}$ Thus the Foreign Affairs Select Committee concluded its review of UK policy in Rakhine and Myanmar; 'there was too much focus by the UK and others in recent years on supporting the "democratic transition" and not enough on atrocity prevention' ${ }^{33}$

It is worth noting the impact Suu Kyi had upon those who visited her from the UK government, not only in the years before the 2017 atrocities but also in their wake. The 2018 UN Fact-Finding Mission was explicit in their criticism of her but this was not - and perhaps still is not - reflected in the UK position.

The State Counsellor, Daw Aung San Suu Kyi, has not used her de facto position as Head of Government, nor her moral authority, to stem or prevent the unfolding events, or seek alternative avenues to meet the Government's responsibility to protect the civilian population or even to reveal and condemn what was happening. On the contrary, the civilian authorities have spread false and hateful narratives; denied the Tatmadaw's wrongdoing; blocked independent investigations, including of the Fact-Finding Mission; and overseen the bulldozing of burned Rohingya villages and the destruction of crime sites and evidence. ${ }^{34}$

The treatment of Suu Kyi is not unique but rather is demonstrative of a common phenomenon in the history of modern mass atrocities where personal

$31 \quad$ Her Majesty's Government Officials, interviewed by the author, London, 17 July 2019.

32 FASC, Violence in Rakhine State, HC435, Q79.

33 ibid., executive summary.

34 United Nations Human Rights Council, Report of the Detailed Findings of the Independent International Fact-Finding Mission on Myanmar, A/HRC/39/CRP.2, 17 September 2018, para. 93 . 
convictions of diplomats that the heads of state they and their peers have known, have dinner with, or been charmed by cannot be capable of or play any part in the perpetration of such atrocious crimes. Brendan Simms's excoriating assessment of UK policy during the atrocities in Bosnia paints a comparable picture of the close ties senior UK officials and MPs enjoyed with President Milošević. ${ }^{35}$ It was a relationship that fed misunderstandings of the violence that was taking place against Bosnia's Muslims and encouraged a strategy that rested upon Milošević turning against his long-time allies and working with the EU, UK, and US in leading a democratic transition. Just as the UK continued to put their faith in Suu Kyi, Lord Owen - the British chief peace negotiator for the EU during the Bosnis crisis - represented a common view when he said in 1994; '[t]he key as always is Milošević. ${ }^{36}$ Frameworks and systems of atrocity prevention when properly applied should help guard against the problems of personality that seem to repeatedly distract policy makers - and often advocates - from the warning signs of identity politics and mass atrocities, particularly at moments of transition.

\subsection{The Failure to Use the Tools at Hand}

Interviews suggest that a direct consequence of the UK's democracy-first strategy and of the close relationship some senior officials and minsters enjoyed with Suu Kyi was the decision not to initiate HMG's primary internal means of assessing risks of conflict and instability. The UK's international risk assessment system leans on two core processes: the Cabinet Office's annual Countries at Risk of Instability (CRI) process and the Joint Analysis of Conflict and Stability (JACS), a cross-government process used to develop National Security Council Strategies and which frames decision-making, programme design, and implementation in Whitehall and in country. A JACS is a strategic assessment used to underpin UK National Security Council Strategies. It was introduced by the UK's Building Stability Overseas Strategy (BSOS) in 2011 as a tool to strengthen cross-government approaches to tackling overseas conflict and instability and to 'identify the situation-specific interventions that will be most likely to succeed in helping to prevent conflict and build stability'. ${ }^{37}$ As per the government guidance note, 'the two main results of a JACS are the shared understanding of the actors involved in and the causes and drivers of conflict in a particular situation' and 'helps the UK Government to understand

35 Brendan Simms, Unfinest Hour: Britain and the Destruction of Bosnia (London: Penguin, 2001).

36 ibid.

37 DFID, FCO and MOD, Building Stability Overseas, p. 24. 
the historical causes of conflict, the relationships between key actors, how it has evolved, and what drives the conflict now'. ${ }^{38}$ The process is commonly initiated when potential risks or major junctures are identified. However, despite the dramatic shift from military dictatorship to a hybrid form of governance in Myanmar, and the chronic context of risk in Rakhine, no conflict analysis of the country or region was undertaken. This was despite internal requests from the Stabilisation Unit. ${ }^{39}$ Interviews with officials present in Myanmar prior to 2017 and from the Stabilisation Unit convey a view that this failure came in part precisely because a comprehensive JACs would have identified concerns regarding Suu Kyi and thus posed a challenge to the democratisation strategy. One official, when asked why the JACS was not initiated, replied 'it would have challenged the narrative $[. .$.$] and that would have been inconvenient'.40$

In the past, the UK government has used the JACS framework as a means of exploring 'the potential triggers and risks for conflict escalation and to develop scenarios in order to design appropriate strategies', as for example regarding Zimbabwe in 2016. 'In 'hot' conflict, the UK government has designed JACS processes to explore how the conflict might develop and evolve and the implications for NSC strategic objectives and to inform discussions around resourcing, for example in Iraq in 2017.41

It was not until November 2017, several months after nearly one million people had fled, that cross-Whitehall Directors commissioned an initial JAcs of the Rakhine State, 'aimed at analysing the key conflict drivers, actors, and dynamics which led to the latest violence. ${ }^{42}$ In 2018 a countrywide JACS was finally initiated. ${ }^{43}$ Not only was this a surprisingly late response to the perpetration of atrocities that began in late August 2017, but even more to the warning signs that had been rising throughout 2017 and the 'trial runs' in $2016 .{ }^{44}$

It is impossible to speculate the impact cross-government analysis of the risks of instability and conflict would have had upon UK policy in Rakhine or Myanmar more broadly. Failure to initiate the process nonetheless illustrates the dangers of its ad hoc nature; it was a decision that lay with ministers rather

38 Stabilisation Unit, Joint Analysis of Conflict and Stability: Guidance Note, 1 June 2017.

39 Her Majesty's Government Officials, interviewed by the author, London, 31 July 2019.

40 Her Majesty's Government Officials, interviewed by the author, London, 17 July 2019.

41 Stabilisation Unit, Joint Analysis of Conflict and Stability.

42 Formal response to the author from Her Majesty's Government, received 23 September 2019.

43 As set out in DFid Burma's Programme for Democratic Change, Annual Review, No. 34699392, Programme Code: 203454, 2018.

44 On trial runs and attempts by the Tatmadaw to test red lines in 2016, see Staunton and Ralph, 'Responsibility to Protect'; Francis Wade, The Enemy Within: Buddhist Violence and the Making of a Muslim 'Other', and ed. (London: Bloomsbury Academic, 2019). 
than an automatic assessment triggered by passing a clear threshold of risk. As a result, the UK's Myanmar policy remained in the hands of individuals rather than being led by focused analysis. Failure to undertake its primary means of context-specific country analysis left the UK without the benefits of its own risk assessment tool. Without the JACS it is unclear what informed the UK's 'understanding of the context and the underlying causal factors of violence in Rakhine State' that was such a 'fundamental precursor to [HMG ] programming'.

This is not to say that had the JACs been initiated, the UK would have been able or willing to do more to help prevent what happened in 2017 in Rakhine. While the JACS is a powerful analytical tool it - like the Cabinet Office annual risk assessment - is not an early warning mechanism. Neither are capable of capturing real-time threats and informing rapid responses. They are processes for analysing longer-term trends and establishing agreed understandings and approaches across government. 'Day to day' monitoring of violence from HMG appears to be less prescriptive and administratively heavy, but also less formalised and more reliant on who is in post at a certain time. Reporting on real-time conflict trends comes from diplomatic missions, development offices, internal analysis, international partners, and open-source information but is relatively ad-hoc.

The bigger question is perhaps why the process was not initiated at the beginning of Myanmar's transition? One reason could be capacity; the JACS is a relatively heavy process, relying on a wide range of sources, including literature reviews, background research and analysis, interviews and data collection with international, national, and local level stakeholders in country and in the UK, as well as internal, cross-government roundtable discussions. It is not undertaken frequently, and indeed, in many country cases it has not yet been done. Another reason could be that the JACS are framed in terms of 'pre-war', 'hot conflict' and 'post-conflict'. Perhaps what experts from the fields of genocide and atrocity prevention saw in Myanmar as deeply concerning risks were not as obvious to those in government charged with viewing risks in the country through a conflict prevention framework.

Even if the JACs had been initiated, it currently operates on a framework of conflict and stability and has not yet committed to integrating specific indicators related to atrocities or identity-based violence. The JACs Framework of Analysis focuses on five core analytical questions: the causes of conflict, who the main actors are, how causes and actors interrelate to create the drivers of conflict, potential triggers for further conflict, and opportunities to reduce instability and promote peace. ${ }^{45}$ While this has the potential to capture threats

45 Causes of conflict and instability, including: power distributions between groups at local, national, and regional levels; exclusion; how resources are shared; how individuals seek 
of identity-based violence, it skims across risk factors for atrocities by not asking for an analysis of vulnerable groups. Adding questions relating to 'who is vulnerable to identity-based violence and why?' in reference to existing questions regarding 'which groups are most excluded?' could be used to flag the importance of this policy priority in future JACS guidelines, particularly if it were backed up by a clear list of guidance indicators as that suggested above. ${ }^{46}$ Recent research on the UK's review of its protection of civilians strategy also suggests that civilian protection is not an analytical lens that is currently highlighted by the JACs. ${ }^{47}$ If an appreciation for those groups vulnerable to identity-based violence was then coupled with questions on local capacities for protection as part of the assessment of opportunities to reduce instability, the JACS could provide a clearer basis for understanding how UK activities could support the prevention of genocide, ethnic cleansing, and other forms of identity-based mass violence outside and during conflict situations. However, if the UK is determined to view its contributions to the prevention of identity-based violence and mass atrocities as part of its approach to conflict prevention, at the very least there should be an expectation that where those tools can add value or help clarify UK atrocity prevention policy, they should be employed.

\subsection{No Integration of Atrocity Risk Indicators}

Emphasis on the wider democracy agenda and no comprehensive country or regional analysis of the roots of conflict, instability, and other manifestations of violence severely curtailed the UK's capacity to respond to worsening

to exploit instability; and how robust local, national, and regional mechanisms are for managing disputes. Main actors involved: their desires, expectations, and capacities; the methods they use to hold power; the sources of their legitimacy; financial resources; external support, vulnerabilities; relation to other actors; incentives and disincentives towards peace or conflict. Conflict dynamics: who is promoting, reinforcing, or benefiting from conflict; the distribution of power; how conflict systems are organised and maintained, such as through ideologies; function, patterns, and durability of the instability. Triggers for further conflict: upcoming activities like elections, return of displaced persons, removal of subsidies; past triggers; cyclical patterns; potential for natural disasters. Opportunities for peace: actors and their capacity to reduce violence; effectiveness of key institutions; expectations of the population on state and state services; role of community-based and non-state institutions; formal and informal mechanisms for conflict management; population livelihoods; role of religious establishments in guiding activities of population. See Stabilisation Unit, Joint Analysis of Conflict and Stability.

46 Ralph, 'Mainstreaming the Responsibility to Protect in UK Strategy' also discusses the JACS and absence of atrocity prevention indicators.

47 Aniseh Bassiri Tabrizi, Amanda Brydon, and Ewan Lawson, The UK Strategy on Protection of Civilians: Insights for the Review Process, Royal United Services Institute Whitehall Report No. 2-19, 18 September 2019. 
signs of systematic discrimination against Rohingya and other minorities or identify other indicators commonly associated with rising atrocity risks. It meant the premise of the country strategy was wrong and HMG lacked the information that could have helped to redress the error. Had the UK's programmes in Rakhine or its embassy been equipped with their own means of recognising, monitoring, and communicating these risk factors or indictors, the UK would, at the very least, have bolstered its own intelligence and had the opportunity to integrate local analysis into UK thinking. All the indicators of extreme identity-based violence had been high for the decade before 2017, before and since the EU lifted its trade embargo with Myanmar in 2013, yet there were no means of monitoring them either from London, Brussels, or on the country level.

Like the JACS, 'DFID Myanmar operates a policy of undertaking conflict-sensitive approaches' and their 'projects and programmes are assessed for their "conflict sensitivity" seeking to improve the extent to which programmes improve peacebuilding opportunities. 48 Interviews with staff who were involved in implementing these programmes or making such assessments often lacked even a basic understanding of where the distinctions between atrocity prevention and conflict prevention lay. Put simply, atrocities were generally seen as violence that follows on from armed conflict and that in seeking to prevent conflict, the UK was inevitably helping to prevent genocide, ethnic cleansing, and crimes against humanity. The processes which propelled the violence of state-led discrimination, dehumanisation, disenfranchisement, divestment of property, sexual violence, and divisive media fell outside of the conceptual and policy frameworks of democratisation and conflict prevention.

Even when the same tools can be used for both conflict prevention and atrocity prevention, how they are applied must be necessarily different: As Bellamy proposes,

[w] hen mobilised for atrocity prevention, common prevention measures must be used appropriately to target atrocity risk and avert the pitfalls of a conflict prevention-dominant mindset, such as a blind culture of neutrality that treats all parties as morally equivalent, the pursuit of negative peace at any price in the face of a credible threat of atrocities, and the tendency to believe that prevention ends when violence begins. ${ }^{49}$

48 Formal response to the author from Her Majesty's Government, received 23 September 2019.

49 Alex J. Bellamy, Mass Atrocities and Armed Conflict: Links, Distinctions, and Implications for the Responsibility to Prevent, Policy Analysis Brief, The Stanley Foundation, February 2011. 
None in the UK Myanmar team had, in 2019, received any kind of training on how to recognise risks of identity-based violence or atrocity. One official confessed to having an unclear understanding about what the differences between mass atrocities are. This lack of confidence and clarity further obscured in-country analysis and embassy-to-London communication; there just was not the necessary understanding, policy framework or common lexicon to measure or raise alarm relating to risks of genocide or other atrocity crimes.

This knowledge gap is not unique to the Myanmar team; it is a common frustration that has been expressed to the author by HMG officials working in at least two other countries where the risks of mass atrocities are high. What risks in the day-to-day are measured, and how they are assessed, seem to fall to the in-country staff; if they have an understanding of atrocity indicators (and the energy to do so), they are more likely to be monitored. According to officials, the UK mission never undertook training in atrocity prevention nor were they equipped with resources to help bridge this knowledge gap. None I spoke to in 2019 were familiar with the UN Framework of Analysis for Atrocity Crimes, a prevention tool which sets out 14 risk factors. ${ }^{50}$ This was in contrast to the UK's South Sudan team who have used the framework for some years and who have been credited by civil society and partners for their contributions to mitigating and preventing some (although evidently not all) atrocities over the past five years.

Likewise, these same gaps can be seen in the UK's national level processes. The Countries at Risk of Instability framework (CRI) has traditionally not incorporated a distinct understanding of atrocity dynamics. Prior analysis of the CRI Guide's risk assessment framework describes it as being based on two core risk factors: the country's formal structures, or resilience; and demands for change, or pressure. ${ }^{51}$ While this may capture certain vulnerabilities, Ralph noted in 2014 that the 'the CRI process has not been given the specific task of assessing the likelihood of mass atrocity'.52 This gap in UK analysis is likely why atrocity risks in Central African Republic were missed by HMG horizon scanning processes in 2014. There is no evidence that this gap has narrowed. As such, it is unlikely that the current CRI includes a register of which countries are likely to experience such crimes or the groups that would be vulnerable.

The absence of national or local monitoring systems focused on atrocity risks meant that warnings of impending mass atrocities received by HM G came

50 United Nations (UN), Framework of Analysis for Atrocity Crimes: A Tool for Prevention, (New York: United Nations, 2014).

$5^{1} \quad$ Ralph, 'Mainstreaming the Responsibility to Protect in UK Strategy'.

$5^{2}$ ibid., p. 18. 
from external sources, including UK and international civil society organisations, rather than its own internal intelligence. Because HMG in Myanmar lacked specific atrocity prevention training and capacity, those officials tasked with monitoring or responding to the human rights crisis in Rakhine had no specific understanding of atrocity crimes, their dynamics, or how their risk factors can be distinct from conflict, civil war, and other manifestations of violence. It appears that, as a result, the atrocities against the Rohingya in autumn 2017 were initially viewed as the consequence of instability and low-level local conflict rather than a climax of a coordinated and planned strategy of discrimination and expulsion.

It is often said that the atrocities in 2017 did not represent a failure of early warning but of early action because the risks facing the Rohingya were well known and well publicised. But the UK struggled without its own internal monitoring system focused upon the atrocity dynamics. In mid-winter 2017, the FCO still had 'not undertaken its own analysis of the situation, nor committed its own expert team to gather evidence. 53

There are clear benefits to integrating a matrix or index of risk factors for identity-based violence into country analysis, particularly if it could take the form of a lighter weight analytical tool contributing to a 'living' document as opposed to the static JACS which require significant effort to update. Such a framework would help the UK to better assess risks of violent extremism, mass atrocities, institutional violence, campaigns against LGBTQ+ communities, and other manifestations. By enhancing its monitoring of the early warning signs that are distinct from the indicators of traditional conflict and instability, the UK would have been more alert to these indicators and therefore have been able to better predict and perhaps prevent the latest episode of identity-based mass violence. ${ }^{54}$

\subsection{No National Strategy of Atrocity Prevention}

While many mistakes and missed opportunities in the UK's Myanmar policy can be attributed to overemphasis of democratisation, an absence of cross-government analysis, and the failure to integrate atrocity prevention monitoring on the country level, the wider problem was that the UK lacked any kind of explicit approach, strategy, or mechanism through which HMG's understanding of and contributions to the mitigation and prevention of mass atrocity crimes could be identified or coordinated. The lack of any kind of domestic policy process or parliamentary precedent charged with determining or 
implementing the UK's treaty obligations to prevent and punish genocide, or its more normative commitments to help protect populations from the risk of atrocity crimes, perpetuated internal uncertainty regarding appropriate terminology to describe the violence and where responsibility for British contributions to genocide prevention or $\mathrm{R}_{2} \mathrm{P}$ lay within the civil service. The absence of a conceptual framework of atrocity prevention, of identity-based violence sensitive analysis, and of structures embedded within Whitehall and the country office in Yangon meant little to no formal cross-departmental procedures tasked with risk assessment, scenario planning, leverage analysis, or internal flag raising could take place. As a result, the UK found itself ill-prepared to respond in-country to the emergency and unable to articulate its approach to predicting, preventing, or protecting people from, mass atrocity violence. ${ }^{55}$ The UK was unable to react on a local level or in its wider Myanmar strategy to the tightening of restrictions on Rohingya in Rakhine. HMG's public narrative remained flawed for too long - tied to Suu Kyi until late 2017 and, until at least 2019, presented the challenges in Rakhine as separate from the wider Myanmar story - as if the escalating structural and physical violence against the Rohingya (and other minorities) was not representative of the democratic progress.

While the UK government recognised Rakhine long before 2017 as a point of concern, without internal means of viewing the situation from the perspective of risks facing populations of potential widespread or systematic violence, HMG contributions to what could be considered as the prevention of atrocities were inevitably disconnected or piecemeal. Thus, while DFID programmes in Rakhine were 'geared around preventing conflict and improving intercommunal relations ${ }^{56}$ - which can help mitigate violence - programme design, funding pots, the wider department, and the embassy had no strategy to address the mounting risks of mass atrocities.

Even these efforts were undermined by other UK activities in Myanmar. Without a clear strategy of atrocity prevention either on a country level or

55 FASC, Violence in Rakhine State, HC 435; FASc, Global Britain: The Responsibility to Protect and Humanitarian Intervention: Government Response to the Committee's Twelfth Report, Fifteenth Special Report of Session 2017-19, HC1719, 19 November 2018; House of Commons International Development Committee (IDC), Bangladesh and Burma: The Rohingya Crisis, Second Report of Session 2017-19, HC504, 16 January 2018; IDC, Bangladesh and Burma: The Rohingya Crisis - Monsoon Preparedness in Cox's Bazar, Third Report of Session 2017-19, HC904, 20 March 2018; IDC, Bangladesh, Burma and the Rohingya Crisis, Fourth Report of Session 2017-19, HC1054, 22 May 2018; IDC, Humanitarian Crises Monitoring: The Rohingya, First Report of Session 2019-21, HC259, 22 May 2020.

56 Formal response to the author from Her Majesty's Government, received 23 September 2019. 
across UK international policy, there was no means of coordinating the UK's various internationally facing departments around its rhetorical commitment to help prevent genocide and other atrocities. This meant that moments of potential leverage were missed, and inconsistency became a problem. After 2011, the UK occupied an almost unique role in Myanmar as it began its transition to more hybrid governance structure. Not only was DFID a leading aid donor to the country but the EU lifted its trade embargo in 2013, before the United States and others, allowing for the UK to build bilateral trade relations despite the escalating anti-Muslim violence in the provinces. According to the UK Department for Trade, UK goods exports to Burma increased by 239 per cent between 2012 and 2013. While this was starting from a very low base, by 2015 there were 40 to 50 British companies estimated to have a presence in the country. ${ }^{57}$ The Chamber of British Commerce in Myanmar was established in July 2014, operating out of the British Embassy. ${ }^{58}$ In 2018 it had a membership of more than 270 companies, both local and international, and hosting over 60 events a year, and 'providing relevant business and political updates, professional training and networking. 59

While critics saw British support for bilateral business in Myanmar as problematic, the UK government understood 'work to promote responsible British business and investment in Myanmar' as 'part of our commitment to Myanmar's economic transition. ${ }^{60}$ But reviewing trade relations offers the possibility of soft leverage and in Myanmar's case this moment was missed. Any office or mechanism charged with viewing UK policy-making from the perspective of trying to prevent atrocities would have alerted relevant HMG staff to the warning signs emerging from Myanmar and initiated a processes of sharing information, scrutinising UK policy, and communicating with other atrocity prevention and local stakeholders here in the UK and abroad. It could have provided advice gathered from previous cases and monitored indicators of risk - and assessed how the UK and/or other actors could best respond. It could have helped to avoid inconsistencies in the UK's policy that undermined efforts that sought to prevent crisis; such as the decision to hold the

57 Department for International Trade (DIT), HMG, Embargos and Sanctions on Burma, 1 August 2012.

$5^{8}$ DIT, HMG, 'Doing Business in Burma (Myanmar): Myanmar Trade and Export Guide, 2014 until 2017', updated 2015, withdrawn in 2020.

59 Website of the British Chamber of Commerce Myanmar, 2019, see British Chamber of Commerce Myanmar, 'The British Chamber of Commerce Myanmar Fifth Birthday Party', https://britishchambermyanmar.eventbank.com/event/british-chamber-of-commerce-fifthbirthday-party-15124/?pk_campaign=widget-event-list, accessed 25 November 2020.

6o Formal response to the author from Her Majesty's Government, received 23 September 2019. 
2014 bilateral trade fair in the same year that the UK Ambassador to the UN, Matthew Rycroft, worked to ensure the Rohingya crisis to be discussed by the UN Security Council. ${ }^{61}$

In its response to the Foreign Affairs Committee's Rakhine report, the Foreign Office reiterated government 'support for mass atrocity prevention and for the principle of the Responsibility to Protect'. However, while the FCO was able to set out its efforts with and funding of external international partners 'to drive international policy on atrocity prevention' in general, it was unable to demonstrate if or how these efforts were replicated in UK policy or implemented via UK activities. ${ }^{62}$ The only mechanism in the UK that currently exists within Whitehall tasked specifically with these responsibilities is the Focal Point for the Responsibility to Protect. ${ }^{63}$ It is a role that has little public image and limited, if modestly increasing, engagement with UK-based atrocity prevention and $\mathrm{R}_{2} \mathrm{P}$ civil society. The office of the $\mathrm{R}_{2} \mathrm{P}$ Focal Point, a position that until the FCO-DFID merger was occupied by the Director of the Multilateral Directorate, has been overstretched and lacked $\mathrm{R}_{2} \mathrm{P}$ or atrocity prevention specific resources. As a result, little is known about how the UK Focal Point for $\mathrm{R}_{2} \mathrm{P}$ functions. It is unclear what actions the office initiated within HMG, the global network of focal points, or in conversation with UN stakeholders regarding Rakhine in 2017. When asked about the role and responsibilities of the $\mathrm{R}_{2} \mathrm{P}$ Focal Point in relation to the UK's Syria policy, the Deputy Director of the Multilateral Directorate and the Minister responsible for UK atrocity prevention policy described a consultative function that sat alongside the other functions of the Director's job description. ${ }^{64}$ It was not a role that officials working in Myanmar in 2017 were aware of.

\subsection{No Internal Communication Channel}

UK missions should play a key role in identifying early warning signs of mass atrocities and, in coordination with Whitehall, devising policy options to respond. However, interviews with former and current FCO and DFID staff in Myanmar and in the Democratic Republic of Congo have highlighted gaps

61 On 17 April, at the request of the UK, the Special Adviser on Myanmar, Vijay Nambiar, briefed Council members in informal consultations under 'any other business'. The briefing focused on the situation in Rakhine.

62 FASC, Violence in Rakhine State and the UK's Response: Government Response to the Committee's First Report, Fourth Special Report of Session 2017-19, HC868, 6 March 2018, p. 15 .

63 Until 2018 this was Paul Williams, also Director of the Multilateral Directorate, FCO; both positions are now held by James Kariuki.

64 FASC, Oral Evidence, HC1005, 11 July 2018. 
that exist between HMG officials in the field, embassies, London and New York that can mean the urgency felt by on-the-ground personnel is lost as information is passed up through the bureaucracy to ministers. ${ }^{65}$ One official who was part of the UK team in Myanmar before and after the 2017 atrocities said 'in hindsight, if we could have convinced people this was about to happen, then you would have had a much stronger response [from the UK government] [...] but without formal tools, it is left to someone's judgement'.66 An official based in another mission where atrocity risks are common said that monitoring and communication across networks was 'active but not systematic', and as a result monitoring risks was 'largely down to individuals and the time they have to dedicate to it'. Officials described needing to fit warnings of rising risks in Rakhine into more general reporting or communication frameworks such as monthly reporting or preparing briefings for ministers which necessarily needed to include information about a range of other matters. There was a sense that concerns could get drowned out, diluted, or lost. One official mooted the idea of a 'whistle-blower policy' for suspected cases of mass atrocity. ${ }^{67}$

The absence of internal government communication across departments as well as between the country team, London, and New York, further inhibited a joined-up UK strategy. Unlike emergent efforts by the UK in Myanmar to bring in British officials working in health, drugs trafficking, and trade as well as development and conflict into their atrocity prevention strategy development, prior to and in the wake of the 2017 atrocities, no such conscious internal communication network existed.

A light-touch internal model of emergency communication protocol, accompanied by clear resources such as checklists and rapid analysis frameworks, would have facilitated mission staff to 'raise the red flag' to colleagues back home, clarify tools and strategies already available, and improve joined-up communications during a period of exceptional challenge when risks of atrocities are expected to rise. Clear alert channels are important in any volatile situation and even more so during times of political upheaval or emergency, such as during the COVID-19 pandemic. Alert channels can be relatively light touch, but communication needs to be clear, providing a 'moving picture' rather than a one-off snapshot, and information needs to be received by those

65 Alexandra Buskie, 'Strengthening the UK's Approach to Atrocity Prevention in the Democratic Republic of Congo', Protection Approaches, forthcoming, 2020.

66 Her Majesty's Government Officials, interviewed by the author, London, 17 July 2019.

67 ibid. 
knowledgeable and prominent enough to influence decision-making if they are to be effective. ${ }^{68}$

\section{$4 \quad$ Towards a New Approach?}

Without a clearly articulated policy or strategy for approaching atrocity risks, nor the means for officials on the ground to trigger a process of analysis, UK officials charged with responding to the dynamics on the ground were left to implement a disconnected policy that sought to place human rights concerns at the heart of its regional development in Rakhine, but only as part of a wider country vision of democratic transition and economic development. It was within this context that the UK government decided in 2014 - in the face of public warnings from genocide prevention and human rights organisations to fund the controversial census that endeavoured to strip Rohingya of citizenship and to hold a bilateral trade fair for Myanmar in London. In the absence of coordinated or cross-cutting government analysis, the opportunity was missed to assess possible points of leverage or identify potential UK complicity with a regime that was explicitly seeking to legally enforce bureaucratic discrimination and structural violence.

Sustained parliamentary scrutiny, internal reflection, and growing dialogue between the UK government and UK atrocity prevention NG O s, led in October 2018 to a commitment from then Foreign Secretary Jeremy Hunt to 'do more' on atrocity prevention. ${ }^{69}$ Then, in July 2019, the government published its national approach to preventing mass atrocities, in which it clarifies that the FCo leads on mass atrocity prevention policy within the UK government, with other parts of Whitehall in supporting roles. Lord Ahmad of Wimbledon, the Minister of State responsible for the United Nations and the Commonwealth, was given oversight of the UK's work on atrocity prevention. It reaffirmed that the FCo's Director of Multilateral Policy as the senior official responsible for these policy areas and serves as the UK's 'Focal Point' for the Responsibility to Protect $\left(\mathrm{R}_{2} \mathrm{P}\right)$. It was the first document to clarify the UK's tools and understanding of atrocity prevention. It includes commitments to early warning and to identify countries at risk of instability, conflict, and atrocities; diplomacy to help de-escalate tensions and resolve disputes; development and

68 Ban Ki-moon, Fulfilling Our Collective Responsibility: International Assistance and the Responsibility to Protect, A/68/947-S/2014/449, 11 July 2014.

69 Jeremey Hunt, 'An Invisible Chain', Keynote Address, Policy Exchange, London, $3_{11}$ October 2018. 
programmatic support to address the root causes of conflict; and defence and policing tools, which may include deployments of UK armed forces, to assist with training and capacity building in the security sector. ${ }^{70}$ It falls considerably short of a national strategy, comes with no resources, and has not even been distributed to relevant HMG staff.

The UK team in Myanmar has also begun to reshape their country policy, seeking to embed a framework of and commitment to atrocity prevention across its constituent parts. Energy and enthusiasm to engage with local, UK-based, and international civil society seems to have been refreshed. The development and implementation of a trial internal communications process better connecting the field and embassy staff with their counterparts in London and New York has already helped contribute to effective actions at the $\mathrm{UN}$ and in Myanmar. The country team in 2020 began a series of consultations with NGO S on the development of an atrocity prevention framework and with local atrocity prevention actors. The country team undertook some initial training on atrocity prevention in late 2020. These steps are modest but signal an important conceptual shift that appears to be supported by Whitehall. Success will depend on the extent to which central government invests in the skills, resources, and systems necessary to embed these new efforts beyond individual committed officials. This will likely be an investment of time more than money but flux in Whitehall regarding the future of UK international policy with the Prime Minister's unfinished integrated review, merger of FCO and DFID, and a post-Brexit mid-pandemic UK Treasury with eyes on the UK's aid budget, even modest resource uplifts for countries such as Myanmar are far from certain. The seizure of power by the military in February 2021 only increases urgency for states like the UK to prioritise and integrate atrocity prevention in their national policies towards Myanmar but there is no guarantee that lesson has been sufficiently internalised by the necessary HMG offices and departments.

\section{5 \\ Conclusions}

The period between summer 2017 when the atrocities began and publication in summer 2019 of the UK's National Approach to Preventing Atrocities was one of growing domestic instability and rising anti-internationalist populism. In the months immediately before the campaign of forced expulsion and violence in Rakhine, the UK was consumed by a surprise general election and 
a result that lost the Conservative government its overall majority, implicitly challenging the public mandate of the $2016 \mathrm{EU}$ referendum and ushering what would become months of mounting political uncertainty. Between 2016 and 2019, the UK had three prime ministers, four foreign secretaries, and six secretaries for international development. During Boris Johnson's short time as Foreign Secretary, the Foreign Office saw unprecedented cuts to its budget, hastening what some have identified as a steady decline of the FCO; in 2019, the FCO's entire budget amounted to barely o.1 per cent of government spending. ${ }^{71}$ Johnson, apparently to support May's Brexit strategy, oversaw the rapid withdrawal in late 2017 of UK diplomats from Asia (including Myanmar), South America, and Africa for EU postings. ${ }^{72}$ As domestic political temperatures continued to rise, challenges to the UK's overseas contributions became part of mainstream parliamentary discourse. Priti Patel, Secretary of State for International Development during the first months of the Rohingya crisis, repeatedly and publicly questioned the legitimacy of the UK's commitment to the 0.7 per cent of GDP development spend, enshrined in law by David Cameron's Development Secretary Andrew Mitchell; in late 2020 this became a reality. ${ }^{73}$ After the snap general election in December 2019 and at the height the Coronavirus lockdown, Johnson made the shock announcement that he would be merging DFID and the FCO. ${ }^{74}$ The UK has rarely been so distracted from the world stage.

And yet, during this period, the UK government has made its most substantial steps forward in articulating its national approach and commitment to preventing mass atrocities. Thus, this analysis presents a case study for the often contradictory nature of norm evolution and policy implementation.

This paper argues that if, as Secretary-General Guterres has urged, states are to integrate prevention commitments throughout their national mechanisms, the $\mathrm{R}_{2} \mathrm{P}$ and atrocity prevention community can indeed continue to make progress in an era where the norm's strength is so weakened in the UN arena. Moreover, paying proper attention to national level understanding, engagement, and implementation necessarily brings into clearer focus the cross-cutting nature of atrocity prevention, in contrast to the more controversial and exceptional matter of armed protective action.

71 Sam Goodman, Running Out of Credit? The Decline of the Foreign Office and the Case for Sustained Funding, Report, British Foreign Policy Group, 18 June 2019.

72 Francis Elliot, 'Asian Embassies Cut by Boris Johnson to Fund EU Diplomats', The Times, 30 December 2017, https://www.thetimes.co.uk/article/asian-embassies-cut-by-boris-johnsonto-fund-eu-diplomats-gl $72 \operatorname{mogh} 7$, accessed 25 November 2020.

73 William Worley, 'Breaking: UK cuts aid budget to $0.5 \%$ of GNI' Devex, 25 November 2020.

74 Bob Seely and James Rogers, Global Britain: A Twenty-First Century Vision (London: Henry Jackson Society, 2019). 
The 2017 Rakhine crisis revealed that in the UK atrocity prevention was still predominately understood as a narrow agenda or a reactive strategy to specific, highly complex crises once the point of mass violence has been reached. The phenomenon of mass atrocities was - is - more frequently viewed in HMG through the prism of individual situations where prevention failed and atrocities have been committed with impunity. This meant that many in the UK continued to conflate calls for prevention with their fears of ill-judged armed intervention. The prevention of future atrocities was therefore, in 2017, still seen in the UK as a morally urgent but politically impossible task. The UK contributed substantially to the humanitarian aid effort in Cox's Bazar, expressed horror at what had passed, but remained reluctant to engage with the drivers and causes of the atrocities themselves. Political will did grow but a bigger problem seems to be that neither government nor opposition knew what could be done; or, worse still, HMG believed they were doing, and had done, all they could.

While predicting and preventing systemic violence is complex, difficult to prove, and often not politically salient, this paper has identified a series of concrete measures the UK could take which would strengthen its national capacity to predict, enhance its approach to prevention, and therefore increase its contribution to the shared responsibility to protect peoples around the world from the gravest crimes. The UK's atrocity prevention 'strategy', such as it existed before recent publication of its national approach, was typically to 'pass up' responsibility to the UN in New York or Geneva without matching contributions via national level activity. Without firmly and explicitly embedding the commitment to prevent atrocities across departments and tools of UK policy, it is difficult to see how the failures in Myanmar will be avoided elsewhere. This would require something of a national strategy supported by a coordinating office or unit. ${ }^{75}$

The extent to which the UK takes forward these lessons will play out as the Johnson government implements the outcomes of the currently ongoing Integrated Review of UK defence, diplomatic, and development policy. In establishing the Atrocities Prevention Board, the US has articulated the challenge as a 'vital' national interest, while other states in Africa and Latin America are developing their own national and regional strategies for prevention. ${ }^{76}$ There is pressure for the UK to follow suit.

75 Kate Ferguson, 'Putting the Principle of Atrocity Prevention at the Heart of British Foreign Policy' in Adam Hug (ed.), Finding Britain's Role in a Changing World: the Principles for Global Britain' (London: Foreign Policy Centre, 2020).

${ }_{76}$ Although it should be noted that the US and the Atrocity Prevention Board failed in Myanmar too. See The White House, Presidential Study Directive on Mass Atrocities, PSD-10, 4 August 2011; Capicotto and Scharf, 'National Mechanisms'. 
While this paper examines UK policy as a means of understanding how national implementation of the collective responsibilities to prevent and protect populations from mass atrocities, the exercise could - and perhaps should - be applied to all the UK's partners in Myanmar and more broadly. There is strategic and normative impetus for states to prioritise and integrate strategies of preventing identity-based violence, including mass atrocities, into their domestic and foreign policy. With the UN Security Council increasingly in deadlock on issues of prevention and protection, it is difficult to see how the principle of $\mathrm{R}_{2} \mathrm{P}$ and the work of preventing atrocities can make much progress without this step. At the same time there are rising calls for actors at the national and international level to assign dedicated prevention positions within governments and international organisations to offer advice and prevention assessment summaries to inform general policy development. If it is indeed agreed that all states must share in the burden of helping to prevent atrocities, all states - but particularly those that seek to play an active role in the world - must now come to see developing national strategies for prevention as a primary means of upholding their domestic and international contributions to this urgent global and shared challenge. 